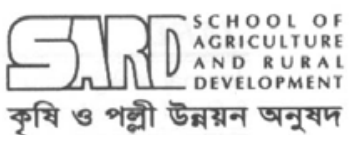

\title{
Comparative Analysis of T. Aman Rice Cultivation under Different Management Practice in Coastal Area
}

\author{
M. A. RAZZAQUE ${ }^{1^{*}}$ AND S. RAFIQUZZAMAN ${ }^{2}$ \\ ${ }^{1}$ RARS, Bangladesh Agricultural Research Institute, Rahmatpur, Barisal, Bangladesh \\ ${ }^{2}$ Pulse Research Sub-Station, Bangladesh Agricultural Research Institute, Madaripur, Bangladesh
}

\begin{abstract}
The field experiment was carried out at Multilocation testing site Barguna in kharif -II seasons of 1999 and 2000 to find out the probable reason of yield gap of T. aman rice (BR-23) between demonstration plot (DP) with Research management and Non-demonstration plot (NDP) with Farmer management practices. Across the years there exists a big gap in yield (1220 kg ha $\left.{ }^{-1}\right)$ between DP and NDP. DP gave about 25.15\% higher yield than NDP due to use of best quality seed, appropriate age of seedlings (30 days), closer spacing, optimum number of seedlings per hill, use of balanced fertilizer and pest control in proper time. Although cultivation cost of DP was higher (Tk.2218 ha ${ }^{-1}$ ) than that of NDP. Demonstration plots showed higher benefit cost ratio (2.28) than non-demonstration plot (1.98).
\end{abstract}

Key words: Coastal area, T. aman rice, farmer practice, research management, yield gap.

\section{INTRODUCTION}

Rice is the staple food of Bangladesh. Bangladesh is not only a rice growing country but also a country of rice eating people (Annon. 1998). Rice is grown in three seasons namely Aus (mid March to mid August), Aman (mid June to November) and Boro (Mid December to mid June). T. aman rice covers about $50.92 \%$ of the rice areas of Bangladesh (BBS, 2005) of which modern t. aman varieties covers 60\% (BBS, 2005). In ganges tidal floodplain Agroecological zone-13 T. aman is the main crop. Agro ecological condition of this area favours the large-scale cultivation of T. aman rice.

Hence the demand for more rice has placed heavy pressure on farmers and agricultural researchers to intensify rice production systems. Due to rapid population growth and urbanization, the cultivated land is gradually decreasing demanding increased output simply to keep pace with the population increase. This is possible only by increasing yield per unit area and by expanding MV's rice cultivation. Rice cultivation is the primary employment activity in Bangladesh (IRRI, 1980). Due to rapid population growth and urbanization, the cultivable land is decreasing day by day. Cultivation of modern varieties (MV) of rice can increase the yield per unit area.

In Bangladesh cropping intensity is very low and crop production are very much dependent on the traditional methods, abouts $80 \%$ of the agricultural land is used for rice cultivation (BBS, 2006). The annual grain production (310.32 tons) is not sufficient to meet the demand of 144 million

*Corresponding author: Scientific Officer, RARS, BARI, Rahmatpur, Barisal, Cell: 01715208814

(C) 2006 School of Agriculture and Rural Development, Bangladesh Open University, All rights reserved. 
people of Bangladesh, which are increasing of the rate of 1.43 percent (BBS, 2006). The population pressure compels the government to import 1.5 million metric tons of food grain every year. Almost $85 \%$ of the population of Bangladesh lives in rural areas having the main occupation of farming. The government of Bangladesh has given the highest priority to increase food availability in the country (Saha et al, 1996). One of the methods to reach this goal of increasing the food sufficiency is the reduction of yield gap of the food grain per unit area. Very little information is available on the gap between research management and farmers practices.

Therefore, to achieve both increased production and employment generation, the area under modern variety of rice should be increased. There is an ample scope to grow modern variety rice in the coastal belt of Bangladesh, where both employment and income share can be increased, But out of 2.85 million hectares of the coastal and off-shore areas, about 0.833 million hectares are arable constituting about $52.8 \%$ of the net cultivable area in 64 thanas of 13 districts (Razzaque et al., 2004). The remaining area is affected by varying degrees of soil salinity. The agricultural production in these areas is very poor and the cropping intensity is much lower than the national cropping intensity (179\%), ranging from $62 \%$ in Chittagong coastal region to $114 \%$ in Patuakhali coastal region (Karim et. al., 1990). In these areas, MV transplant aman can be planted intensively to augment income and welfare for the low-income farmers. Location specific research may be more useful for making any recommendation for a particular region.

For a particular crop there exist wide variations in yield between what is observed in research management demonstrations and in the farmers practice. Variations in time and method of planting and cultural operations and level of input use might be causing such yield differences. Management practices and input use level are likely to be influenced by various socio-economic factors such as farmer's age, education, occupation, resource base and access to information. There fore, the present study was under taken to pinpoint the reasons of yield gap and know the economic logic behind it and know the profitability.

\section{MATERIALS AND METHODS}

A field experiment was conducted at Multilocation testing site Barguna during the kharif-Il season of 1999 and 2000. Five demonstrations were carried out in the site. The unit plot size was $8 \mathrm{~m} \times 5 \mathrm{~m}$. Thirty days old seedling of BR-23 rice was transplanted on 10 September maintaining $25 \mathrm{~cm} x$ $15 \mathrm{~cm}$ spacing with 5 seedlings per hill in both the years. Fertilizer were applied $\mathrm{N}_{2} \mathrm{O}_{5} \mathrm{~K}_{2} \mathrm{O} @ 35-$ $12-24 \mathrm{~kg} \mathrm{ha}^{-1}$ in the form of urea, triple super phosphate (TSP) and muriate of potash (MP). One third of urea, whole TSP and MP were applied during the final land preparation. The rest of urea was applied as top-dressed 20 and 42 days after transplanting. Rice was harvested between 10 to 12 December in both the year. At maturity stage of rice data on yield attributes were recorded from 10 randomly selected hills per plot. Yield data was recorded from whole plot.

In addition to demonstration plots as above 30 plots owning by 30 farmers (NDP) T aman crops were selected randomly in each year. Farmers selected plots were monitored (surveyed) for necessary data collection with the help of a pre-designed schedule. Date of sowing \& maturity were same as DP and NDP plots. All activities/operations such as time of weeding, number of pesticide application, number of seedling planting, source of seed were monitored and recorded to the schedule just after completion of the activity. More than $80 \%$ of the farmers are directly or indirectly dependent on agricultural income. The farm size was medium to large and 3-4 effective family members are consists in each farm. Most of the farmers are illiterates and they did not know how applied modern technology.

\section{RESULTS AND DISCUSSION}

\section{Socio-economic profile}

Table 1 shows the socio-economic characteristics of the surveyed farmers. The average family size comprises eight to nine members per family, which is higher than national statistics (5.2) [BBS, 2005]. The effective family labour per family was three to four persons. About 40 percent farmers had primary education and majority of the respondents were illiterate. The majority of the farmers belonged to small and medium size farm lebels. About 78 to 82 percent of the farmers reported 
agriculture as the main source of income generation. The soil of the surveyed /experimental site was clay to silty clay as reported by the majority farmers (78 to $82 \%$ ).

Table 1. Socio-economic profile of the farmers in the experimental/surveyed area

\begin{tabular}{ll}
\hline Factors & Range \\
\hline Av. Age of the farmers(Yrs.) & $30-50$ \\
Family size(no.) & $8.20-9.20$ \\
Adult male & $2.48-3.25$ \\
Adult female & $2.49-2.85$ \\
Children & $2.70-3.40$ \\
Effective labour & $3.44-4.40$ \\
Educational level of farmers (\%) & \\
Illiterate & $45.00-51.85$ \\
Primary level & $41.00-40.74$ \\
Secondary level & $14.00-7.41$ \\
Av. Farm size (ha) & $1.19-.79$ \\
Av. Owned land (ha) & $0.98-.60$ \\
Farmers opinion about soil type (\%) & \\
Clay & $18.00-22.00$ \\
Silty clay & $82.00-78.00$ \\
Source of income (\%) & \\
Agriculture & $78.00-82.00$ \\
Business & $10.00-12.00$ \\
Service & $12.00-8.00$ \\
Farmers adopting method (\%) & \\
Marginal & $8-10$ \\
Small & $47-50$ \\
Medium & $39-36$ \\
Large & $6-4$ \\
\hline
\end{tabular}

Marginal group = less than $0.01 \mathrm{ha}$; Small group $=0.01$ to $1.00 \mathrm{ha}$;

Medium group $=1.01$ ha to 2.00 ha $;$ Large group $=2.01$ ha and above.

It is noted that agriculture was the major occupation in the study area. The soil in the study area was mainly silty clay (Table 1 ). About 40 percent of the farmers in the area were literate which is above national average.

\section{Yield and yield contributing characters}

Yield and yield contributing characters of rice are shown in table 3. NDP showed higher number of effective tillers hill ${ }^{-1}$, filled grain panicle ${ }^{-1}$ than DP. DP plots showed higher hill $\mathrm{m}^{-2}$ grain yield and straw yield due to higher plant population per square metre than NDP.

\section{Input use, cost and return}

Table-4 shows the input use, cost and return from cultivating T.aman in one hectare of land. The average human labour requires in one hectare of NDP was 145 man days ha ${ }^{-1}$ of which $46 \%$ was provided from the farmers own family. Use of human labour in demonstration plot (160 man days $\mathrm{ha}^{-1}$ ) was 9.37 percent higher than NDP.

The average seed rate used by the farmers in NDP was $50 \mathrm{~kg} / \mathrm{ha}$, which was $18 \%$ higher than that in DP $\left(30 \mathrm{~kg} \mathrm{ha}^{-1}\right)$. Seed rate was higher in NDP due to farmer used higher seedling per hill. Farmers used seed from their own source or purchase by their local market. Fertilizer used in DP was N $36 \mathrm{~kg}$ $\mathrm{ha}^{-1}, \mathrm{P}_{2} \mathrm{O}_{5} 10 \mathrm{~kg} \mathrm{ha}^{-1}$ and $\mathrm{K}_{2} \mathrm{O} 24 \mathrm{~kg} \mathrm{ha}^{-1}$. For cultivation of transplant aman in one hectare of land 46 $\mathrm{kg} \mathrm{N}$ was used in NDP, which was higher than DP but no TSP and MP fertilizer, was used in NDP. The main reason behind the use of unbalanced fertilizer by the farmers was that the recommended dosage was unknown to them. Other reason was high prize of fertilizer, shortage of cash capital etc. Cost of fertilizer in DP (Tk. $1168 \mathrm{ha}^{-1}$ ) was $48.65 \%$ higher than NDP $\left(T k .600 \mathrm{ha}^{-1}\right)$.

Average per hectare variable cost of production was Tk. $16768 \mathrm{ha}^{-1}$ in DP and Tk. $14550 \mathrm{ha}^{-1}$ in NDP. Average gross margin from transplant aman in DP was Tk. $21657 \mathrm{ha}^{-1}$ and in NDP was Tk. $14327 \mathrm{ha}^{-1}$. Benefit cost ratio was 2.29 and 1.98 in DP and NDP respectively on total variable cost 
basis. Demonstration plot were consists higher hill per square metre and higher 1000 grains weight compare than non demonstration plot as a result higher yield obtained in demonstration plot (Table 2).

Table 2. Agronomic practices used in demonstration plot and non-demonstration plot

\begin{tabular}{lll}
\hline Parameter & DP & NDP \\
\hline Transplanting time & 10 Sep. & $3-15$ Sep. \\
$\mathrm{Hill}^{2} \mathrm{~m}^{2}$ & 26.6 & 13.3 \\
Seedling/hill & 5 & 10 \\
Fertilizer $\mathrm{N} \mathrm{P}_{2} \mathrm{O}_{5} \mathrm{~K}_{2} \mathrm{O} @ \mathrm{~kg} / \mathrm{ha}$ & $36-10-24$ & $46-0-0$ \\
$\mathrm{~N} 1^{\mathrm{ST}}$. top dress (DAT) & 20 & $22-25$ \\
$\mathrm{~N} 2^{\text {nd }}$. top dress & 42 & - \\
1000 grain wt. $\left.^{-1}\right)$ & 20.4 & 20.2 \\
Yield kg ha $^{-1}$ & 4850 & 3630 \\
\hline
\end{tabular}

DP = Demonstration Plot, NDP Non Demonstration Plot

Table 3. Yield and yield contributing character of T.aman (pooled of 1999 and 2000)

\begin{tabular}{lccccccc}
\hline Management & $\begin{array}{c}\text { Spacing } \\
\mathrm{cm}\end{array}$ & Hill m & $\begin{array}{c}\text { Effective } \\
\text { tiller hill }^{-1}\end{array}$ & $\begin{array}{c}\text { Filled grain } \\
\text { panicle }^{-1}\end{array}$ & $\begin{array}{c}1000 \text { grain } \\
\text { wt. (g) }\end{array}$ & $\begin{array}{c}\text { Yield } \\
\mathrm{kg} \mathrm{ha}^{-1}\end{array}$ & $\begin{array}{c}\text { Straw yield } \\
\mathrm{kg} \mathrm{ha}^{-1}\end{array}$ \\
\hline DP & $25 \times 15$ & 26.6 & 11 & 82 & 20.4 & 4850 & 5125 \\
NDP & $30 \times 25$ & 13.3 & 16 & 85 & 20.2 & 3630 & 4130 \\
\hline
\end{tabular}

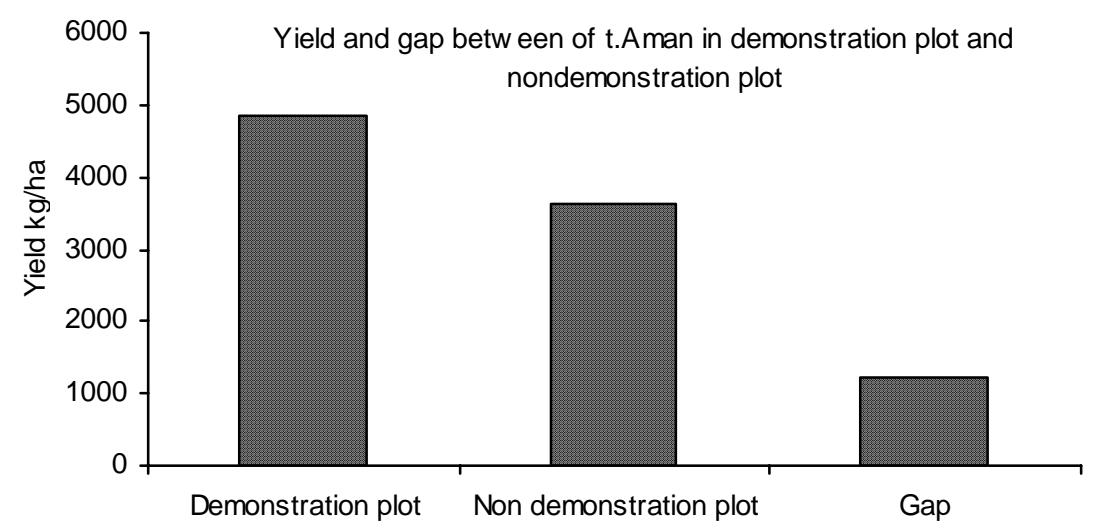

Fig. 1. Yield gap between demonstration and non demonstration plot of T. aman

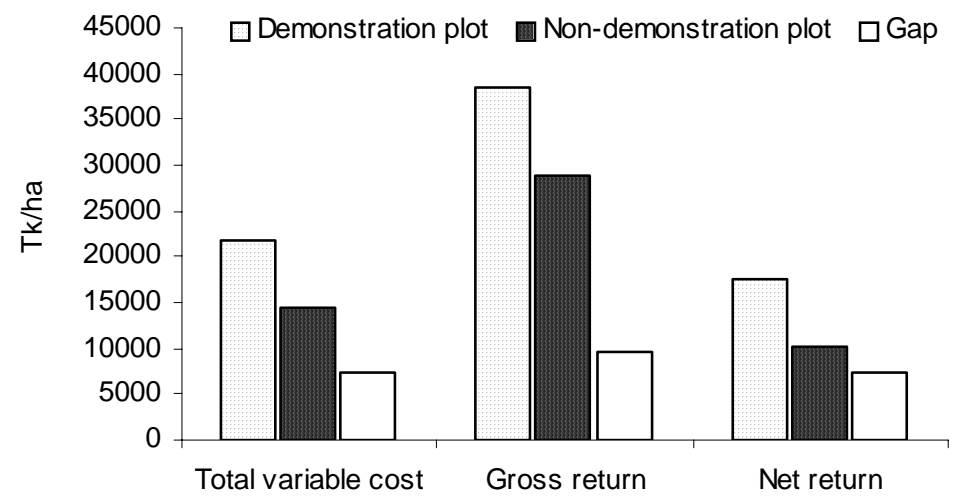

Fig. 2. Return gap between different situations of T. aman in Barguna 
Table 4. Input use, cost and return from cultivation of transplant aman

\begin{tabular}{|c|c|c|c|c|}
\hline \multirow[t]{2}{*}{ Particular } & \multicolumn{2}{|c|}{$\mathrm{DP}$} & \multicolumn{2}{|c|}{ NDP } \\
\hline & Quantity & Value $\left(\right.$ Tk.ha $\left.{ }^{-1}\right)$ & Quantity & Value $\left(T_{k} \cdot h^{-1}\right)$ \\
\hline Humane labour (man days) & 160 & 11200 & 145 & 10150 \\
\hline Power tiller (Pair days) & - & 1700 & - & 1500 \\
\hline Seed $\left(k g ~ h a^{-1}\right)$ & 30 & 450 & 50 & 750 \\
\hline$N\left(\mathrm{~kg} \mathrm{ha}^{-1}\right)$ & 36 & 468 & 100 & 600 \\
\hline $\mathrm{P}_{2} \mathrm{O}_{5}\left(\mathrm{~kg} \mathrm{ha}^{-1}\right)$ & 10 & 300 & & \\
\hline $\mathrm{K}_{2} \mathrm{O}\left(\mathrm{kg} \mathrm{ha}^{-1}\right)$ & 24 & 400 & & \\
\hline Pesticide $\left(T_{k} h^{-1}\right)$ & & 350 & & \\
\hline Rent of sprayer $\left(T_{k} h^{-1}\right)$ & & 100 & & \\
\hline Int. operational cost $\left(\mathrm{Tk} \mathrm{ha}^{-1}\right)$ & & 600 & & 500 \\
\hline Carrying cost of rice $\left(\mathrm{Tk} \mathrm{ha}^{-1}\right)$ & & 500 & & 450 \\
\hline Threshing of rice $\left(\mathrm{Tk} \mathrm{ha}^{-1}\right)$ & & 500 & & 400 \\
\hline Storage of straw $\left(\mathrm{Tk} \mathrm{ha}^{-1}\right)$ & & 200 & & 200 \\
\hline Total variable cost $\left(T_{k} h^{-1}\right)$ & & 16768 & & 14550 \\
\hline Opportunity cost of Land & & 4000 & & 4000 \\
\hline Total cost $\left(T k \mathrm{ha}^{-1}\right)$ & & 20768 & & 18550 \\
\hline Yield $\left(\mathrm{kg} \mathrm{ha}^{-1}\right)$ & 4850 & & 3630 & \\
\hline Price $\left(\mathrm{Tk} \mathrm{kg}^{-1}\right)$ & 7.50 & 36375 & 7.50 & 27225 \\
\hline Straw (Tk ha $\left.{ }^{-1}\right)$ & 5125 & & 4130 & \\
\hline Price $\left(T k . \mathrm{kg}^{-1}\right)$ & 0.40 & 2050 & 0.40 & 1652 \\
\hline Gross return & & 38425 & & 28877 \\
\hline Gross margin & & & & \\
\hline TVC basis & & 21657 & & 14327 \\
\hline Net return & & 17657 & & 10327 \\
\hline BCR: TVC basis & & 2.29 & & 1.98 \\
\hline BCR: TC basis & & 1.85 & & 1.56 \\
\hline
\end{tabular}

TVC: Total Variable Cost, TC : Total Cost, BCR: Benefit Cost Ratio

\section{Yield gap}

There exists a big gap between demonstration and non-demonstration plot of transplant aman (BR23) in yield (1220 kg ha-1) (Fig.1) Gross return (TK $9548 \mathrm{ha}^{-1}$ ) net return (Tk $7330 \mathrm{ha}^{-1}$ ) and variable cost (Tk $2218 \mathrm{ha}^{-1}$ ) (Fig.2). Main reason behind this gap was use of wider spacing in non demonstration plots $(30 \mathrm{~cm} \times 25 \mathrm{~cm})$ In demonstration plot entire seed was purchased from BADC and their quality was good. In NDP the farmers used their own seeds or bought from the local market, which was less quality than BADC.

Table 5. Farmers opinions (\%) on constraints to growing MV aman rice in the surveyed area.

\begin{tabular}{lcc}
\hline Constraints & Percentage & Rank \\
\hline Lack of credit & 45 & 5 \\
Inadequate animal power & 35 & 6 \\
High cost of fertilizer & 80 & 1 \\
Non -availability of fertilizer & 60 & 3 \\
High cost of labour & 45 & 5 \\
High cost of pesticide & 52 & 4 \\
Insects/disease problem & 45 & 5 \\
Non availability of quality seed & 70 & 2 \\
Salinity problem & 30 & 7 \\
Drought problem & 25 & 9 \\
Heavy rainfall & 32 & 8 \\
\hline
\end{tabular}

In this location farmers opinion of growing $\mathrm{MV}$ aman rice high cost of fertilizer is the $1^{\text {st }}$ constraints and Unavailability of quality seed is the $2^{\text {nd }}$ constraints for cultivation of modern $t$. aman rice (Table 5). 


\section{Farmers reaction}

"Would you like to expand your areas for cultivation of T. aman with recommended practice?" was one of the questions put forward to the farmers. Of this $47 \%$ replied in the affirmative while $30 \%$ no answer and $23 \%$ did not intend to change.

\section{CONCLUSION}

Rice can play an important role on overall economy of our country. Farmers were found to obtain lower level of yield potentials following poor management practice as a result yield was not satisfactory. If farmers use recommended package like closer spacing, lower number seedling per hill, use of balance fertilizer, pest control in proper time and 30 days old seedlings thus they will be able to produce optimum yield. However, there was a great scope for higher yield \& net return by adoption of recommended production technology at farm level. This should be ensuring by providing balance fertilizer and supply of good quality seed, which will promote to increase the yield of MV rice and minimize the present yield gap. The constraints faced by the farmers were high cost of fertilizer, quality seed, lack of credit, insect and disease problem. BADC will provide quality seed in proper time. Agricultural extension service will be strengthening for farmer's knowledge improved in modern technology. Therefore all the complimentary production inputs should be ensured for successful crop production.

\section{LITERATURE CITED}

Annonymous. 1998. Problem and prospects for suitable intensification of rice production in Bangladesh. Project publication no. 12. TCTTI Dhaka p-1.

BBS. 2005. The statistical Yearbook of Bangladesh. Bangladesh Bureau of Statistics, Ministry of planning .Dhaka. Bangladesh.

BBS. 2006. The statistical Yearbook of Bangladesh. Bangladesh Bureau of Statistics, Ministry of planning .Dhaka. Bangladesh.

IRRI. 1980. Proc. of a symposium on the agrometereology of the rice crop. Los Banos, Philippines.

Karim, Z., Hossain, S. G. and Ahmed, M. 1990. Salinity problems and crop intensification in the coastal regions of Bangladesh, BARC, Farmgate, Dhaka.

Nasiruddin, M. 1993. "Rice production, Ecotypes concept and research strategy for Bangladesh" pages 123-133 in proceedings of the workshop on Experience with modern rice cultivation in Bangladesh. 8-10 June.1993.BRRI, Gazipur-1701.

Razzqaque, M. A., Rafiquazaman, S., Kabir, A. H. M. F and Alam, M. S. 2004. Economics of mv t. aman rice cultivation in reearch management versus farmer's management practice in some selected sites of tidal flood zone. Bangladesh J. Agril. Res. 29 (1), 129-136.

Saha, J. K. M, Amiruzzaman, J. C, Chaudhury, M. A and Solaiman, A. M. 1996. A study of post harvest practice on paddy, wheat and pulses crop in selected areas of Gazipur District. Bangladesh J. Agril. Res. 21 (1 \& 2), 225-231. 